\title{
A NEW PERSPECTIVE ON FOREIGN LANGUAGE APTI- TUDE RESEARCH: BUILDING AND SUPPORTING A CASE FOR "WORKING MEMORY AS LANGUAGE APTITUDE"
}

\author{
Zhisheng Wen \\ Hong Kong Shue Yan University
}

Peter Skehan

Chinese University of Hong Kong

\begin{abstract}
:
The present paper proposes and argues a case for incorporating the working memory (WM) construct as a component of foreign language aptitude. As such, it first briefly reviews previous research on foreign language aptitude, which lays the ground for the proposal. Then, by drawing on recent research from both the fields of cognitive psychology and second language acquisition, the paper will summarize the key representative theoretical models, major claims and empirical evidence supporting the role of WM in different aspects of L2 learning, such as listening, reading, speaking, writing and interpreting, thus rendering the proposal a feasible blueprint for future research on foreign language aptitude.
\end{abstract}


Keywords: Foreign language aptitude, working memory, SLA.

\section{Introduction}

Even casual observations in our daily life reveal to us that some people learn a foreign language easier, faster or better than others do (Grigorenko, Sternberg \& Ehrman, 2000). This commonplace phenomenon is best encapsulated by the theoretical construct of foreign language aptitude which presupposes that "there is a specific talent for learning foreign languages which exhibits considerable variation between individual learners" (Dörnyei \& Skehan, 2003: 590). Such an underlying assumption of foreign language aptitude has been put to considerable empirical tests as early as the 50s and 60 s of the last century.

Starting from the 1970s, however, research into foreign language aptitude has somehow languished, with "relatively little empirical work and little theorizing" (Skehan, 2002: 69). Such marginalized interest partly stems from two major criticisms charged against the concept of foreign language aptitude (see Skehan, 2002; Dörnyei \& Skehan, 2003): first, for its anti-egalitarian nature in the sense that a low aptitude score labels a language loser of complete no hope; second, for its indecent origin associated with the outdated audio-lingual methodologies that ran anathema to the increasingly dominating communicative classrooms. In addition to these two reasons, Skehan has also reminded us of the existence of an additional factor that may have helped to account for this lack of interest, i.e. language aptitude has been perceived as a stumbling block by publishers of many language textbooks and teaching materials that cannot afford to cater for potential consumers' individual needs.

Despite this bleak scenario, research into foreign language aptitude has somehow survived and even managed to gain renewed 
momentum in the last few years (Dörnyei, 2005; R. Ellis, 2004; Robinson, 2005 \& 2007; Stansfield \& Winke, 2008). What is most striking for these new developments is that, accumulating evidence seems to have pointed at the lack of validity of the two criticisms leveled at the concept of foreign language aptitude (Wen, 2005; cf. Sáfár \& Kormos, 2008). In light of these new developments, the present paper attempts to provide an updated and comprehensive review of major research studies into aptitude in the post-Carroll era. Even more so, the second part of the paper will be devoted to delineating a new conceptualization of foreign language aptitude, in which we will argue a case for the recent proposal of "working memory as foreign language aptitude", thus positing working memory as the central component of the foreign language aptitude construct.

\section{Foreign language aptitude research: A brief historical account}

\subsection{Carroll's contributions}

No review of foreign language aptitude research can fail to mention the American psychologist J. B. Carroll and his work. At the very least, he has dominated this sub-area of applied linguistics with four unsurpassable contributions: First, for his conceptualization of aptitude as speed of learning in which he operationalizes aptitude in terms of the rate (i.e. speed) of learning a foreign language in the context of some sort of formal instruction, be it a language course or a self-study program (see Sawyer \& Ranta, 2001). Second, for his formulation of a model of school learning in which he offers a possible explanation for the interactions between variables comprising aptitude in order to predict learning outcomes in a classroom setting (cf. Skehan, 1986b for a more developed view). Third, for his MLAT test (Carroll and Sapon, 1959) that "measured, as well 
as anything can, some of the components of individual variation in ability to speak a FL" (Spolsky, 1995: 322). As a matter of fact, the MLAT has become something of a model guiding almost allsubsequent aptitude research (see Sawyer \& Ranta, 2001). Fourth, for his conceptualization of foreign language aptitude as containing multiple-components which, as Skehan (2002) pointed out, has proved to be more enduring and interesting even than the MLAT test battery itself. These classical four components are shown in Table 1 (see Dörnyei \& Skehan 2003: 592):

Table 1. Carroll's Four-Factor Aptitude Model

\begin{tabular}{ll}
\hline Aptitude Components & Definitions of Abilities \\
\hline Phonemic coding ability & $\begin{array}{l}\text { Capacity to code unfamiliar sound so that } \\
\text { it can be retained. }\end{array}$ \\
Grammatical sensitivity & $\begin{array}{l}\text { Capacity to identify the functions that } \\
\text { words fulfil in sentences. }\end{array}$ \\
$\begin{array}{l}\text { Inductive language } \\
\text { learning ability }\end{array}$ & $\begin{array}{l}\text { Capacity to extrapolate from given corpus } \\
\text { to create new sentences. }\end{array}$ \\
Associative memory & Capacity to form links in memory. \\
\hline
\end{tabular}

\subsection{Post-Carroll aptitude research}

Most research on foreign language aptitude following the publication of the MLAT can be grouped into three major categories (also see Skehan, 2002): (1) measurement oriented research that targets the development of aptitude tests themselves; (2) research based on the different components of aptitude as conceptualized by Carroll; (3) research which sets out to address aptitude-treatment interactions. In order to have a complete grasp of these lines of research, the empirical studies in each of these categories are summarized in Table 2 (together with other orientations) along with their major findings. 
Table 2. Summary of Post-MLAT Aptitude Research (based on Wen, 2005: 385)

\begin{tabular}{|c|c|c|}
\hline Orientations & Representative Studies & $\begin{array}{l}\text { Major Findings and } \\
\text { Implications }\end{array}$ \\
\hline $\begin{array}{l}\text { Measurement- } \\
\text { oriented }\end{array}$ & $\begin{array}{l}\text { Pimsleur's PLAB, 1966; } \\
\text { Green's York Language } \\
\text { Aptitude Test, 1975; } \\
\text { Petersen and Al-Haik's } \\
\text { DLAB, 1976; Parry and } \\
\text { Child's VORD, 1990; } \\
\text { Sternberg and Ehrman's } \\
\text { CANAL-F, } 2000\end{array}$ & $\begin{array}{l}\text { Psychometric in nature; } \\
\text { Empirically based; } \\
\text { Mostly were MLAT } \\
\text { alternatives or } \\
\text { complementary tests; } \\
\text { Mostly associated with } \\
\text { military or government } \\
\text { initiatives/funding. }\end{array}$ \\
\hline $\begin{array}{l}\text { Components- } \\
\text { oriented }\end{array}$ & $\begin{array}{l}\text { Sparks and Ganschow, } \\
\text { 1991; Skehan, } 1982 \text { \& } \\
\text { 1986a; Sasaki, 1996; } \\
\text { Ranta, } 2002\end{array}$ & $\begin{array}{l}\text { The concept of factor- } \\
\text { components is still } \\
\text { viable; } \\
\text { Relatively little research } \\
\text { has been conducted; } \\
\text { Much room for } \\
\text { development (esp. } \\
\text { memory). }\end{array}$ \\
\hline $\begin{array}{l}\text { Aptitude- } \\
\text { treatment } \\
\text { interaction: } \\
\text { General }\end{array}$ & $\begin{array}{l}\text { Reves, 1982; Wesche, } \\
\text { 1981; Robinson, } 1995 \text { \& } \\
\text { 2002; Erlam, } 2005\end{array}$ & $\begin{array}{l}\text { aptitude information } \\
\text { (profile) is not only } \\
\text { desirable but also } \\
\text { has tremendous } \\
\text { pedagogical } \\
\text { implications under } \\
\text { different L2 learning } \\
\text { conditions. }\end{array}$ \\
\hline $\begin{array}{l}\text { Aptitude and } \\
\text { age }\end{array}$ & $\begin{array}{l}\text { Johnson \& Newport, } \\
\text { 1989; Dekeyser, 2000; } \\
\text { Harley and Hart, 1997 \& } \\
2002\end{array}$ & $\begin{array}{l}\text { Younger learners } \\
\text { tend to show higher } \\
\text { correlations with } \\
\text { memory components } \\
\text { and older learners with } \\
\text { analytical components. }\end{array}$ \\
\hline
\end{tabular}


Aptitude and intelligence

Relationship between $\mathrm{L} 1$ and $\mathrm{L} 2$ abilities
Skehan, 1982; Wesche, Edwards \& Wells, 1982; Sasaki, 1996;

Skehan, 1986b and 1990;
Skehan reported low to moderate correlations; Wesche et al \& Sasaki reported moderate correlations.

Aptitude is a product of two separate groups of influences: inner capacity for learning and the ability to handle language in a decontextualized way.

When all these research studies are put into perspective, the following preliminary conclusions can be safely drawn: First, despite the earlier criticisms (in the 1970s \& 1980s) of being outdated and ineffective, the concept of foreign language aptitude is still relevant to foreign language learning. Furthermore, the effect of foreign language aptitude is not confined to traditional instructed settings, but is also viable under different learning conditions or under different learning contexts in today's communicative classrooms; second, despite the importance of the four factors characterizing foreign language aptitude, research studies looking into them have been relatively scarce. This is particularly so with the case of the memory component, which stands in sharp contrast with the 'cognitive revolution' (Carroll, 1990) taking place in the psychology field. It is small wonder that Carroll, in his later review of aptitude research that mainly focused on studies delineating the components of foreign language aptitude, admitted that there might be other types of memory that could be predictive of language achievement and should entail future research. In view of this, next we will argue 
how the concept of working memory (WM) proves to be the best candidate for the type of memory that is most predictive.

\section{WM as foreign language aptitude: Theoretical and empirical supports}

We believe that, in order to compensate for the limitations of the previous research paradigm of foreign language aptitude, WM with its dependence on later developments of cognitive psychology, may hold the very key to elaborating the concept of foreign language aptitude (also see Sawyer \& Ranta, 2001). However, as has been cautioned elsewhere (Wen, 2007), the assumption of WM as a component of language aptitude should be based on three pre-requisites: firstly, there are individual differences in WM among L2 learners; secondly, these individual differences in WM can be reliably and validly measured; thirdly, WM plays a constant and significant role in second language acquisition processes and L2 development. The following section explicates the construct and assesses its relevance.

\subsection{The WM construct}

Working memory (WM), the concept originally proposed by Baddeley and Hitch (1974), is generally referred to as the cognitive capacity to simultaneously store and process information in real time (Harrington \& Sawyer, 1992). Despite much heated debate about the nature of WM in the cognitive psychology field (see Miyake \& Shah, 1999, Andrade, 2001 and 2008; Conway, Jarrold, Kane, Miyake \& Towse 2007, for recent comprehensive reviews of different WM models), three conceptualizations of the construct related to language learning have received general consensus in the psychology field (Miyake \& Shah, 1999; Conway et al., 2007). First, there is structure to the WM construct, thus making it a multicomponent cognitive construct: a central executive responsible for 
information coordination, control and attention allocation; two slave systems responsible for handling phonological information (the phonological loop) and visual spatial information (the visuo-spatial sketchpad), respectively; and an episodic buffer, added to the model in 2000, which is a limited-capacity store capable of integrating information from different sources in a multidimensional code (see Repovs \& Baddeley, 2006). Second, WM contains both storage and processing functions and there are resource limitations (similar to available attention) to these two cognitive functions, which may result in a trade-off relationship when handling complex cognitive tasks (Daneman \& Carpenter, 1980). Third, what we work on in WM is what may become part of our long term memory (LTM), that is to say, WM serves as a gateway to LTM. WM used in this sense distinguishes itself from traditional short-term memory (STM) in that it is considered as an independent temporary cognitive workspace or computational arena used for sequential cognitive processes, such as the comprehension and production of language (Miyake \& Friedman, 1998; also see Miyake \& Shah, 1999).

\subsection{WM and language learning: Theoretical assumptions}

Up to now, a wide range of studies have looked into the different components of WM and their relationship to language learning. In terms of WM and first language (L1) learning, the work from two broad research camps stands out (also see N. Ellis, 2005; Juffs, 2006): first, there is the British camp which is represented by cognitive psychologists like Alan Baddeley and Susan Gathercole, among others. This group of researchers have generally focused their attention on the phonological loop of the WM model and investigated its involvement in different aspects of language learning (vocabulary acquisition in particular). For example, Gathercole and Baddeley in their seminal work published as early 
as 1993 comprehensively evaluated the detailed implications of all three components of WM in the five central aspects of language learning: vocabulary acquisition, speech production, reading development, skilled reading and comprehension (see Table 3 for details). Later Baddeley, Gathercole \& Papagno (1998) based on an updated review of the important role of the phonological loop in acquiring the new phonological forms of a language, proposed it as the language learning device.

Table 3. WM and L1 Learning (based on Gathercole \& Baddeley, 1993:232)

\begin{tabular}{lll}
\hline $\begin{array}{l}\text { Language } \\
\text { Activities }\end{array}$ & Phonological Loop & Central Executive \\
\hline Comprehension & $\begin{array}{l}\text { Used to maintain a } \\
\text { phonological record } \\
\text { that can be consulted } \\
\text { during off-line language } \\
\text { processing }\end{array}$ & $\begin{array}{l}\text { Involved in processing } \\
\text { syntactic and semantic } \\
\text { information and storing } \\
\text { products of processing }\end{array}$ \\
$\begin{array}{lll}\text { Vocabulary } \\
\text { acquisition }\end{array}$ & $\begin{array}{l}\text { Critical for the long-term } \\
\text { learning of phonological } \\
\text { forms of new words }\end{array}$ & $\begin{array}{l}\text { Involved in interpreting } \\
\text { the semantic } \\
\text { characteristics of new } \\
\text { words? }\end{array}$ \\
$\begin{array}{l}\text { Learning to } \\
\text { read }\end{array}$ & $\begin{array}{l}\text { Contributes to the } \\
\text { development of a } \\
\text { phonological recoding } \\
\text { strategy }\end{array}$ & unknown (as of 1993) \\
Reading & $\begin{array}{l}\text { None, except when } \\
\text { complex judgments } \\
\text { about phonological } \\
\text { structure required }\end{array}$ & unknown (as of 1993) \\
none (as of 1993) & $\begin{array}{l}\text { Involved in planning the } \\
\text { conceptual content of } \\
\text { speech? }\end{array}$ \\
\hline $\begin{array}{l}\text { Speech } \\
\text { production }\end{array}$ & & \\
\hline
\end{tabular}


In slight contrast, on the other side of the Atlantic, there is also the so-called North American WM research camp which is represented by cognitive psychologist like Meredith Daneman, Randal Engle and Akira Miyake, among many others. They have placed more emphasis on the individual differences in central executive of WM and its effects on language processing and comprehension, such as resolution of linguistic ambiguity, the parsing of syntactically complex structures, the on-line generation of inferences, the comprehension and production of words in context etc.(cited from Miyake \& Friedman, 1998: 343). Though with a distinct focus on different aspects of the WM construct, both research camps have pointed to the significant role played by WM in first language learning.

In recent years, an important role of WM has also been ascribed to second language acquisition (SLA) by a number of cognitive psychologists and SLA researchers with a cognitive and psycholinguistic perspective (see Yoshimura, 2001). Their arguments for the implication of WM in SLA are generally built upon a number of assumptions (see Wen, 2007 for a recent comprehensive review). First, unlike first language acquisition which depends more on universal grammar (UG), SLA is generally considered to be constrained by general learning mechanisms (WM being one of these), so it is likely that WM plays an equal, if not more important role in SLA. Second, unlike the process of first language acquisition which is dominated by automatic processing, SLA is characterized by controlled processing, which naturally demands more cognitive resources, thus relying more on WM. Third, other SLA researchers like Skehan $(1998,2002)$ have speculated that, given the fact that WM components (together with other aptitude constructs) are implicated in different SLA stages (including input processes, central processing and output processing) and various SLA cognitive processes or operations within these 
stages (noticing, pattern recognition, automaticity, for instance), the important role of WM in SLA is self-evident (see Table 4 for details). For example, a larger WM will make noticing more likely to occur, which will greatly facilitate L2 learners' attention to focus on form (FonF) in the dominantly meaning-focused communicative classrooms that are common today (e.g. Mackey, Philp, Egi, Fujii \& Tatsumi, 2002; Sagarra, 2007; Sáfár \& Kormos, 2008).

Table 4. SLA Cognitive Processes and Aptitude Constructs (Skehan, 1998 \& 2002)

\begin{tabular}{|c|c|c|}
\hline SLA Stages & $\begin{array}{l}\text { Language Operational } \\
\text { Mechanisms }\end{array}$ & Aptitude Constructs \\
\hline \multirow{6}{*}{$\begin{array}{l}\text { Language } \\
\text { Input } \\
\text { Central } \\
\text { Processing } \\
\text { Language } \\
\text { Output }\end{array}$} & $\begin{array}{l}\text { Input Processing } \\
\text { (segmentation) }\end{array}$ & $\begin{array}{l}\text { Attentional Control } \\
\text { Working Memory }\end{array}$ \\
\hline & Noticing & $\begin{array}{l}\text { Phonemic Coding Ability } \\
\text { Working Memory }\end{array}$ \\
\hline & Pattern Recognition & $\begin{array}{l}\text { Phonemic Coding Ability } \\
\text { Working Memory } \\
\text { Language analysis Ability }\end{array}$ \\
\hline & $\begin{array}{l}\text { Pattern Restructuring } \\
\text { and Manipulations }\end{array}$ & $\begin{array}{l}\text { Language analysis Ability } \\
\text { Working Memory }\end{array}$ \\
\hline & Pattern Control & $\begin{array}{l}\text { Automatization } \\
\text { Working Memory }\end{array}$ \\
\hline & Pattern Integration & $\begin{array}{l}\text { Chunking } \\
\text { Retrieval Memory }\end{array}$ \\
\hline
\end{tabular}

Fourth, SLA is in essence a process of sequence learning and WM plays an important role in the chunking process of these linguistic sequences and consequently influences vocabulary acquisition and grammar learning to a large extent (N. Ellis, 1996; N. Ellis \& Sinclair, 1996; Williams \& Lovatt, 2005). Fifth, at least in highlyskilled L2 users, L2 processing draws from similar WM resources as 
L1 processing (Miyake \& Friedman, 1998). Given the important role played by WM in SLA, these scholars from both fields of cognitive psychology and SLA have thus proposed to incorporate WM as a central component of the foreign language aptitude construct, with a view to modifying or even replacing Carroll's original conceptualization of the concept (Miyake \& Friedman, 1998; also see Wen, 2007; Sawyer \& Ranta, 2001).

\subsection{WM and L2 skills development: empirical support}

\section{(1) WM and L2 Listening}

The concept of WM as limited cognitive resources implies a significant impact on complex tasks such as language comprehension. In the process of listening, for example, listeners normally need to go through six stages (Clark \& Clark, 1977): first, they take in the raw speech and retain a phonological representation of it in WM; then, they need to segment the phonological representation; next, they organize (or parse) the emerging segmentation into constituents and identify their content and function; after they identify each constituent, they use it to construct the underlying propositions, which are continually building into a hierarchy of more complex propositions, i.e. they extract meaning; next they will formulate a response (even if this only means to keep on listening); once meaning has been identified in the form of propositions for a constituent, memory is purged for the phonological form, and only the meaning is retained. As a result, verbatim wording is forgotten. These operations are complex and also pressured. Hence the need to store information and process it rapidly so that working memory capacity is not overloaded.

In terms of WM \& L2 listening, Gu \& Wang (2007) explored the role of executive working memory (EWM) on the listening process 
and its relationship with listening comprehension scores among Chinese EFL learners $(N=59)$ at the university level. They found that EWM (as measured by reading span tasks in both L1 and L2 of the participants) was an effective predictor of the participants' listening comprehension performance, suggesting that a higher EWM is more conducive to listening comprehension. More importantly, they also found that although both EWM measures (in L1 and L2) correlated significantly with listening scores, the EWM measure in the L2 proved to be more effective in predicting participants' listening comprehension $\left(0.646^{*}\right.$ vs. $0.539^{*}$ for the total score of WM). This second finding prompted the researchers to claim that it would be more suitable to use EWM measures (such as the reading span task, Daneman \& Carpenter, 1980) in the participants' L2 when investigating the relationship between WM and specific areas of SLA (such as L2 listening).

\section{(2) WM and L2 Reading}

Similar to listening, the reading process also consists of a series of comprehension stages. The effects of WM in these reading subcomponents are obvious. Koda (2005) cogently points out that, "once extracted from print, lexical information must be consolidated into larger, meaningful chunks, such as phrases, sentences, and paragraphs and WM plays a pivotal role in this critical process." So it is not surprising to claim that, "beyond lexical access, virtually every operation in reading relies on WM" (p. 200). With respect to the involvement of WM in reading comprehension and development, considerable empirical research in L1 has been carried out, consistently pointing to high correlations between WM capacity (mostly measured by the reading span task of Daneman \& Carpenter, 1980) and reading comprehension scores (see Daneman \& Merikle, 
1996 for a meta analysis of 77 studies). In SLA research, an increasing number of studies have also replicated these results from $L 1$ reading research. Harrington \& Sawyer (1992), for example, measured the digit span, word span and reading span of Japanese college learners of English and their TOEFL subsections, and found that L2 reading span correlated strongly with TOEFL subsections of grammar (0.57) \& reading (0.54). Berquist (1997), following Harrington \& Sawyer's study, also measured college students' L1 (French) and L2 (English) word span, L1 and L2 reading span, and correlated these measures with TOEIC subsections and found similar results: L2 reading span correlated significantly with TOEIC listening (0.26), reading (0.46) and total scores (0.41). Miyake \& Friedman (1998) used the listening version of Daneman \& Carpenter's reading span task to explore the relationship between WM and L2 cue acquisition and syntactic comprehension. Subjects were 58 Japanese learners of English who completed L1 Japanese and L2 English reading span tasks and comprehension tasks. The results from path analysis indicated that L2 reading span correlated significantly with cue preference $(-0.37)$, and syntactic comprehension (0.38).

More recently, Walter (2004) adopted Waters \& Caplan's (1996) version of the reading span task (indexed by composite scores from logicality judgment, reaction time and recall span) and found that EWM correlated significantly with summary completion scores ( $\mathrm{r}$ $\left.=0.73^{\star}\right)$ and remote pro-form resolution scores $\left(r=0.52^{\star}\right)$, thus supporting the instrumental role of EWM in the transfer of L1 to L2 reading skills. Lesser (2007) also adopted Waters \& Caplan's (1996) version of the reading span task and investigated the interaction effects of topic familiarity and EWM on comprehending and processing the grammatical form of future tense morphology (in Spanish). Results indicated the individual differences in EWM (measured by the 
reading span task) did play some role, but such a role for EWM only emerged depending on participants' previous knowledge about the text topics. In other words, this relationship between EWM and L2 grammatical processing is mediated by or interacts with long-term knowledge of the subject mater (operationalized as topic familiarity).

\section{(3) WM and L2 Speaking}

In terms of speaking research, Levelt's speech production model is probably the most often cited by SLA researchers (cited from Payne \& Whitney, 2002). According to Levelt (1989), speech production involves three stages: Conceptualization, where the preverbal message (the non-language communicative intention) is generated and maintained in the WM; Formulation, where the lemmas or lexical items appropriate to the pre-verbal message are selected (and which then trigger a process called grammatical encoding); and Articulation, where the articulatory plan resulted from the formulator is executed. Previously, Levelt believed that only the stage of conceptualising demands WM, while the stage of formulation (which includes lexical retrieval and syntactic planning) and articulation are "largely automatic" (Levelt, 1989, p. 21, though see Ferreira \& Pashler, 2002 and Hartsuiker \& Barkhuyen, 2006 for counter arguments). So far three attempts have been made to adapt Levelt's speech model to account for bilingual production processes (cited from Payne \& Whitney, 2002). However, as Payne \&Whitney argued, these three adaptations of Levelt's model all failed to address the need to understand how individual differences in WM capacity may boost or constrain the language processing capabilities of second language learners and therefore they believed that Levelt's model should be augmented with concepts from WM so as to better account for second language speech production. 
Payne \& Whitney (2002) further pointed out that less fluent L2 speakers and fluent L2 speakers both need to draw on WM resources in their speech production, though such demands may differ qualitatively and quantitatively from each other: less fluent speakers, for example, may expend a great deal of their attentional resources on lower level processes such as retrieving appropriate words from their mental lexicon, determining the correct surface structure or syntax, and selecting the corresponding lexemes or phonological units for the words in the utterance, which consequently place large demands on the phonological loop of WM to maintain the intermediate products of calculations as the speakers cycle through Levelt's model. Then the central executive of WM is required to make judgments about the correctness of the lemmas selected, the syntax and sound structure of the utterance, what information needs to be retrieved from long-term memory, and what new updated information needs to be put back into the phonological loop for storage etc. For more fluent speakers, however, many of these low-level processes occur without much conscious attention, so attentional resources can be saved to focus on greater subtleties of expression. In other words, both the central executive and the phonological loop of WM are directly implicated in the L2 speaking process. Such being the case, WM exerts a significant impact on L2 speech performance.

Recent years have witnessed a number of SLA studies that have corroborated the view that WM capacity (the phonological loop in particular) of individual L2 learners can have a great effect on SLA, including the acquisition of L2 lexical knowledge (N. Ellis, 1996 \& 2001), and even on the acquisition of L2 grammar rules (Williams, 1999; Williams \& Lovatt, 2005). Other research studies have also shown that WM can indeed predict L2 oral development in synchronous computer mediated communication context (Payne 
\& Whitney, 2002; Payne \& Ross, 2005) and classroom context (Fortkamp, 1999 \& 2003; O’Brien, Segalowitz, Collentine \& Freed 2006 \& 2007; Mizera, 2006). Most relevantly, the two studies by O'Brien and colleagues explicated how the phonological loop of WM (or phonological memory as they called it) plays different roles for early and later L2 oral development: it contributes significantly to the development of L2 narrative skills at earlier stages of L2 learning (accounting for $17.5 \%$ of the variance), but it is more conducive to the correct use of function words when L2 learners reach a relatively high proficiency level (accounting for $15.7 \%$ of variance). Their findings resonated to a large degree with Payne \& Whitney's speculations that WM plays a distinctive role for less fluent and more fluent L2 speakers. Taken together, these preliminary results from several existing SLA studies have indeed shown that WM can predict L2 oral speech to a certain extent in classroom contexts(Fortkamp, 1999 \& 2003; Mizera, 2006; French, 2006), in a study-abroad context (O'Brien et al., 2007) and in a synchronous computer mediated communication (CMC) context (Payne \& Whitney, 2002; Payne \& Ross, 2005), thus establishing the initial link between WM and L2 speech production and L2 oral development (French \& O’Brien, 2008).

\section{(4) WM and L2 Writing}

As with speaking, writing has generally been viewed as a complex activity that involves many simultaneous sub-goals and interacting processes, whose overall quality is limited by the writer's WM resources (Swanson \& Berninger, 1996). Within a cognitive view of writing research, there has been a recent modest growth to explicitly relate WM effects to the cognitive demands of the writing process. Such efforts are manifested in the different models incorporating WM in the writing process (see Chanquoy 
\& Alamargot, 2002 for a review) and the most influential and often cited model is that proposed by Kellogg (1996 \& 1999). Paralleling Levelt's speech production model, Kellogg's WM writing model assumes three systems of written production: formulation, execution and monitoring. Each of these systems in turn possesses two basic processes and many other sub-processes. According to Kellogg, five of these six basic processes make specific demands on the central executive, verbal or phonological, and visual/spatial components of WM (see Table 4), with only the execution of programmed muscle movements proceeding fully automatically without any demands on WM. An increasing number of empirical studies have found that WM correlates significantly with a number of writing measures, particularly those related to text generation (e.g. Swanson \& Berninger, 1996; McCutchen, 2000; Kellogg, 2001 \& 2004). In sharp contrast with the large number of studies looking into the role of $\mathrm{WM}$ in written production, studies investigating the role of WM in L2 writing have been scarce indeed (the only exception seems to be Abu-Rabia, 2003). The field is still awaiting further research heading towards this direction.

Table 5. WM Components and the Writing Processes (Kellogg, 1999:46)

\begin{tabular}{llll}
\hline Basic Processes & & WM Components & \\
\hline & Spatial & Central Executive & Verbal \\
Planning & Yes & Yes & \\
Translating & Yes & Yes & \\
Programming & & Yes & \\
Executing & & & Yes \\
Reading & & Yes & \\
Editing & & Yes & \\
\hline
\end{tabular}




\section{(5) WM and Bilingual Interpretation}

Simultaneous Interpretation (SI) is one of the most complex language-processing tasks imaginable (Christoffels \& de Groot, 2005; Christoffels, de Groot \& Kroll, 2006). During SI, one has to listen to and comprehend the input utterances in one language (the source language in this case), keep it in WM until it has been recoded and can be produced in the target language, and produce the translation of an earlier part of the input, all of these need to be done at the same time, thus making use of WM resources to their extreme (cited from Mizuno, 2005: 741). No other language task combines the need to comprehend and produce speech concurrently, and to simultaneously command and control two languages as SI does, so overwhelming demands will be placed on the central executive of WM. Even more so, the delay between input and output in SI is on average only about two to three seconds or four to five words (cited from Christoffels, de Groot \& Waldorp, 2003: 202), so the limited resources of WM unavoidably implicate a competition (or trade-off) between the storage and processing functions, leading to potential bottlenecks in SI (Gile, 1997).

So far, a number of models have been proposed to account for the involvement of WM in interpreting (e.g. Daro \& Fabbro, 1994; Mizuno, 2005). However, despite the intriguing relationship between WM and SI, empirical studies looking into it have been relatively few in number (Cowan, 2000; also see Christoffels \& de Groot, 2005). Among these, Daro \& Fabbro (1994) successfully demonstrated the complexity of the interpreting process and its demands on WM, and suggested that WM is mainly disrupted by a mechanism of phonological interference in interpreting. Padilla, Bajo, Canas \& Padilla (1995) and Bajo, Padilla \& Padilla (2000) provided evidence that interpreting practice develops efficient 
WM skills in that professional interpreters generally have a higher average memory capacity than all other novice groups (e.g. student interpreters, novice interpreters, non-interpreters). Christoffels et al. (2003) identified some of the basic cognitive skills involved in SI with a particular focus on the roles of memory and lexical retrieval and found that digit span and reading span were associated with SI performance (though less strongly than with the picture naming task). Liu, Schallert \& Carroll (2004) used the listening span as a measure of general cognitive ability and found that the development of specific skills in managing competing demands on limited cognitive resources contributed to professional interpreters' consistently superior performance in the interpretation task. Most recently, Kopke \& Nespoulous, (2006) also found significant group differences (between groups of expert interpreters and novice interpreters) on a free recall task with articulatory suppression, in a category probe task and a listening span task, thus lending empirical support to the assumption that the central executive of WM played a key role in the interpretation process. While not ignoring other factors influencing the interpreting performance (e.g. linguistic factors), these studies have pinpointed the urgent need to further explore the role of WM in the cognitive process of interpretation.

\section{Conclusion}

Through the above analysis, it is hoped that this paper has demonstrated that the concept of foreign language aptitude is still a viable and necessary concept for language learning and SLA research. More importantly, the present paper has shown that, besides being able to compensate for the limitations in previous foreign language aptitude research (Carroll's time), the prospect of incorporating $\mathrm{WM}$ as a key component in foreign language aptitude is possible, 
feasible and promising indeed. To recapitulate, three (pre)conditions have arisen to allow WM to be the best candidate component of foreign language aptitude: first, there are variations in WM capacity that are specific to individual L2 learners and these variations can be measured (by a whole range of WM span tasks); second, WM plays a very important role in various SLA stages and cognitive processes and such effects are constant and pervasive; third, different components of WM (the phonological loop and the central executive in particular) have been found to be highly correlated with different aspects of L2 performance and developments (vocabulary, grammar acquisition) and specific L2 skills development (listening, reading, speaking, writing and interpreting). Given such a central role played by WM in second language acquisition and L2 development, it is high time we reopened the research agenda of foreign language aptitude by incorporating WM capacity as the most effective modification to the existing aptitude construct (Wen, 2007). For now, the SLA field is looking to the next phase of research framed within this potentially promising and fruitful construct.

\section{References}

Abu-Rabia, S. (2003). The influence of working memory on reading and creative writing processes in a second language. Educational Psychology, 23, 209-222.

Andrade, J. (2001). Working memory in perspective. Hove, England: Taylor $\&$ Francis.

Andrade J. (2008). Memory: Critical concepts in psychology. London; New York: Routledge.

Baddeley, A.D. (2003). Working memory and language: an overview. Journal of Communication Disorders, 36,189-208.

Baddeley, A. D., \& Hitch, G. (1974). Working memory. In G.A. Bower (Ed.), The psychology of learning and motivation, Vol. 8. New York: Academic Press. 
Baddeley, A., Gathercole, S. E., \& Papagno, C. (1998). The phonological loop as a language learning device. Psychological Review, 105, 158-173.

Bajo, M. T., Padilla, F. \& Padilla, P. (2000). Comprehension processes in simultaneous interpreting. In A. Chesterman, N. Gallardo San Salvador \& Y. Gambier (eds.), Translation in Context, (pp. 127-142). Amsterdam: John Benjamins.

Berquist, B. (1997). Individual differences in working memory span and L2 proficiency: Capacity or processing efficiency?. In Sorace, Proceedings of the GALA' 1997 Conference on language acquisition. Edinburgh: The University of Edinburgh.

Carroll, J. B. (1981). Twenty-five years of research on foreign language aptitude . In K. C. Diller, Individual Differences and Universals in Language Learning Aptitude. Rowley, MA: Newbury House.

Carroll, J. B. (1990). Cognitive abilities in foreign language aptitude: Then and now. In T. Parry \& C. W. Stansfield (eds.), Language Aptitude Reconsidered. Englewood Cliffs, NJ: Prentice Hall.

Carroll, J. B. \& S. Sapon. (1959/2002). Modern Language Aptitude Test (MLAT). New York: The Psychological Corporation. (Reprinted in 2002 by Second Language Testing Inc.)

Chanquoy, L. \& Alamargot, D. (2002). Working memory and writing: Model evolution and research assessment. L'Annee Psychologique, 102, 363-398.

Christoffels, I. K., De Groot, A. M. B \& J. F. Kroll, (2006). Memory and language skills in simultaneous interpreters: The role of expertise and language proficiency. Journal of Memory and Language, 54, 324-345.

Clark H. H. \& Clark E. V. (1977). Psychology and language. New York: Harcourt Brace Jovanovic.

Conway, A. R. A., Jarrold, C., Kane, M. J., Miyake, A., \& Towse, J. N. (Eds.) (2007). Variation in working memory. New York: Oxford University Press.

Cowan, N. (2000). Processing limits of selective attention and working memory: Potential implications for interpreting. Interpreting, 5(2), 117146. 
Daneman, M., \& Carpenter, P.A. (1980). Individual differences in working memory and reading. Journal of Verbal Learning and Verbal Behaviour, 19, 450-466.

Daneman, M. \& Merikle, P. M. (1996). Working memory and language comprehension: A meta-analysis. Psychonomic Bulletin and Review, 3, 422-433.

Darò, V., \& Fabbro, F. (1994). Verbal memory during simultaneous interpretation: Effects of phonological interference. Applied Linguistics, $15,365-381$.

Dekeyser, R. (2000). The robustness of critical period effects in second language acquisition. Studies in Second Language Acquisition, 22, 499533.

Dörnyei Z. \& P. Skehan, (2003). Individual differences in second language learning. In Doughty and M. Long (eds.), The handbook of second language acquisition. Oxford: Blackwell.

Ellis, N.C., (1996). Sequencing in SLA: phonological memory, chunking and points of order. Studies in Second Language Acquisition, 18, 91-126.

Ellis, N.C., (2005). At the interface: Dynamic interactions of explicit and implicit language knowledge. Studies in Second Language Learning, 27, 305-352.

Ellis, N.C., \& Sinclair, S. G. (1996). Working memory in the acquisition of vocabulary and syntax: Putting language in good order. The Quarterly Journal of Experimental Psychology, 49A(1), 234-250.

Ellis, R. (2004). Individual differences in second language learning. In Davies, A and C. Elder. (Eds.). The handbook of applied linguistics. Oxford: Blackwell.

Erlam, R. (2005). Language aptitude and its relationship to instructional effectiveness in second language acquisition [J]. Language Teaching Research, 9: 147-171.

Ferreira, V., \& Pashler, H. (2002). Central bottleneck influences on the processing stages of word production. Journal of Experimental Psychology: Learning, Memory, and Cognition, 28, 1187-1199. 
Fortkamp, M.B.M. (1999). Working memory capacity and aspects of L2 speech production. Communication and Cognition, 32, 259-296.

Fortkamp, M.B.M. (2003). Working memory capacity and fluency, accuracy, complexity and lexical density in L2 speech production. Fragmentos, 24, 69-104.

French L. (2006). Phonological working memory and second language acquisition: a developmental study of francophone children learning English in Quebec. Lewiston, N.Y.: Edwin Mellen Press.

French, L. M. \& O'Brien, I. (2008). Phonological memory and children's second language grammar learning. Applied Psycholinguistics, 29, 463487.

Gathercole, S. and Baddeley, A. (1993). Working Memory and Language. Hove, UK: Lawrence Erlbaum Associates.

Green, P. (1975). The language laboratory in school: The York study. London: Oliver and Boyd.

Grigorenko, E.L., Sternberg, R.J. \& Ehrman, M. (2000). A theory-based approach to the measurement of foreign language aptitude: the CANAL-F theory and test. Modern Language Journal 84, 390-405.

Gu., S. \& Wang, T. (2007). Study on the relationship between working memory and EFL listening comprehension. CELEA Journal, 30, 46-56.

Harley B. \& Hart, D. (1997). Language aptitude and second language proficiency in classroom learners of different starting ages. Studies in Second Language Acquisition, 19, 379-400.

Harley B. \& Hart, D. (2002). Age, aptitude and second language learning on a bilingual exchange. In P. Robinson, (ed.).

Harrington M. \& Sawyer, M. (1992). L2 working memory capacity and L2 reading skill. Studies in Second Language Acquisition, 14, 25-38.

Hartsuiker, R.J., \& P. N. Barkhuysen. (2006). Language production and working memory: The case of subject-verb agreement. Language and Cognitive Processes, 21, 181-214.

Johnson, J. S. \& Newport, E. L. (1989). Critical period effects in second language learning: The influence of maturational state on the acquisition of English as a second language. Cognitive Psychology, 21, 60-99. 
Juffs, A. (2006). Working memory, second language acquisition and loweducated second language and literacy learners. LOT Occasional Papers: Netherlands Graduate School of Linguistics, 89-104.

Kellogg, R. (1996). A model of working memory in writing. In Levy C. \& S. Ransdell (Eds.), The science of writing. Mahwah, New Jersey: Erlbaum.

Kellogg, R. (1999). Components of working memory in text production. In Torrance, M \& G.C. Geffery (Eds.), The cognitive demands of writing. Amsterdam: Amsterdam University Press.

Kellogg, R. (2001). Competition for working memory among writing processes. American Journal of Psychology, 114, 175-192.

Kellogg, R. (2004). Working memory components in written sentence generation. American Journal of Psychology, 117, 341-361.

Koda, K. (2005). Insights into second language reading: A cross-linguistic approach. Cambridge: Cambridge University Press.

Kopke, B. \& Nespoulous, J. (2006). Working memory performance in expert and novice interpreters. Interpreting, 8(1), 1-23.

Kormos, J., \& Sáfár, A. (2008). Phonological short term-memory, working memory and foreign language performance in intensive language learning. Bilingualism: Language and Cognition, 11, 261-271.

Leeser, M. J. (2007). Learner-based factors in L2 reading comprehension and processing grammatical forms: Topic familiarity and working memory. Language Learning, 57/2, 229-270.

Levelt, W. J. M. (1989). Speaking: From intention to articulation. Cambridge, MA: The MIT Press.

Liu, M., Schallert, D \& P. Carroll. (2004). Working memory and expertise in simultaneous interpreting. Interpreting, 6(1), 19-42.

Mackey, A., J. Philp, T. Egi, A. Fujii \& T Tatsumi. (2002). Individual differences in working memory, noticing of interactional feedback and L2 development. In Robinson (ed.).

McCutchen D. (2000). Knowledge, processing, and working memory: Implications for a theory of writing. Educational Psychologist, 35, 13-23.

McLaughlin, B. (1995). Aptitude from an information processing perspective. Language Testing, 11, 364-381. 
Mizera, G. J. (2006). Working memory and L2 oral fluency. Unpublished $\mathrm{PhD}$ dissertation submitted to University of Pittsburg.

Miyake, A. \& Friedman N.P. (1998). Individual differences in second language proficiency: working memory as language aptitude. In Healey A.F. and L. J. Bourne (Eds.). Foreign language learning: Psycholinguistic studies on training and retention. Mahwah, N.J.: Lawrence Erlbaum.

Miyake, A. \& Shah, P. (1999). Models of working memory: Mechanisms of active maintenance and executive control. New York: Cambridge University Press.

Mizuno, A. (2005). Process model for simultaneous interpreting and working memory. Meta, 50(22), 739-752.

O’Brien, I., Segalowitz, N., Collentine, J \& B. Freed. (2006). Phonological memory and lexical, narrative, and grammatical skills in second language oral production by adult learners. Applied Psycholinguistics, $27,377-402$.

O’Brien, I., Segalowitz, N., Collentine, J \& B. Freed. (2007). Phonological memory predicts second language oral fluency gains in adults. Studies in Second Language Acquisition, 29, 557-582.

Padilla, P., Bajo, M.T., Canas, J. J.\& Padilla, F. (1995). Cognitive processes of memory in simultaneous interpretation. In J. Tommola (ed.), Topics in Interpreting Research, pp. 61-72. Turku: University of Turku.

Parry, T. S., \& Child, J. R. (1990). Preliminary investigation of the relationship between VORD, MLAT, and language proficiency. In T. Parry \& C. W. Stansfield (Eds.), Language aptitude reconsidered (pp. 3066). Englewood Cliffs, NJ: Prentice Hall.

Payne, J. S. \& P. J. Whitney. (2002). Developing L2 oral proficiency through synchronous CMC: Output, working memory, and interlanguage development. CALICO Journal, 20, 7-32.

Payne, J. S. \& Ross, B. (2005). Working memory, synchronous CMC, L2 oral proficiency development. Language Learning and Technology, 9(3), 35-54.

Petersen, C. R. \& AL-Haik, A. R. (1976). The development of the Defense Language Aptitude Battery (DLAB). Educational and Psychological Measurement, 6, 369-380. 
Pimsleur, P. (1966). Pimsleur Language Aptitude Battery (PLAB). New York: Harcourt, Brace, Jovanovich.

Ranta, L. (2002). Analytical ability in L2 classrooms. In P. Robinson (ed.).

Repovs, G \& A. Baddeley. (2006). The multi-component model of working memory: explorations in experimental cognitive psychology. Neuroscience, 139(1), 5-21.

Reves, T. (1982). What makes a good language learner? Unpublished PhD dissertation, Hebrew University of Jerusalem.

Robinson P. (1995). Attention, memory and the "noticing" hypothesis. Language Learning, 45, 283-331.

Robinson, P. (2002). Effects of individual differences in intelligence, aptitude and working memory on incidental second language learning: A replication and extension of Reber, Walkenfield and Hernstadt (1991). In P. Robinson (Ed.), Individual differences and second language instruction (pp. 211-266). Philadelphia: Benjamins.

Robinson, P. (2005). Aptitude and second language acquisition. Annual Review of Applied Linguistics, 25, 46-73.

Robinson, P. (2007). Aptitudes, abilities, contexts, and practice. In Dekeyser, R. (Ed.) Practice in a second language: Perspectives from applied linguistics and cognitive psychology (pp. 256-286). Cambridge University Press.

Sáfár, A., Kormos, J. (2008). Revisiting problems with foreign language aptitude. International Review of Applied Linguistics, 46, 113-136.

Sagarra, N. (2007). From CALL to face-to-face interaction: The effect of computer-delivered recasts and working memory on L2 development. In A. Mackey (Ed.), Conversational Interaction in Second Language Acquisition: A Series of Empirical Studies. Oxford: Oxford University Press.

Sasaki, M. (1996). Second language proficiency, foreign language aptitude, and intelligence. New York: Peter Lang.

Sawyer M. \& L. Ranta. (2001). Aptitude, individual differences, and instructional design. In P. Robinson (ed.). Cognition and instructed second language learning. Oxford, OUP. 
Skehan, P. (1982). Memory and motivation in language aptitude testing. Unpublished Ph.D. dissertation. University of London. UK.

Skehan, P. (1986a). Where does language aptitude come from? In P. Meara (Ed.), Spoken language (pp. 95-113). London: Center for Information on Language Teaching.

Skehan, P. (1986b). The role of foreign language aptitude in a model of school learning. Language Testing, 3, 188-221.

Skehan, P. (1986c). Cluster analysis and the identification of learner types.

In V. Cook (ed.), Experimental approaches to second language learning (pp. 81-94). Oxford: Pergamon.

Skehan, P. (1998). A cognitive approach to language learning. Oxford University Press, Oxford.

Skehan, P. (2002). Theorising and updating aptitude. In P. Robinson (ed.). Individual differences and instructed language learning. Amsterdam/ Philadelphia: John Benjamins.

Sparks R., \& Ganschow, L. (1991). Foreign language learning differences: Affective or native language aptitude differences? Modern Language Journal, 75, 3-16.

Spolsky, B. (1995). Prognostication and language aptitude testing. Language Testing, 12, 321-340.

Stansfield, C \& P. Winke, (2008). Aptitude for SLA. In E. Shohamy (ed.), The encyclopedia of language and education, Vol. 7. Heidelberg, Germany: Springer Verlag.

Swanson, H. L. \& V. W. Berninger. (1996). Individual differences in children's working memory and writing skills. Journal of Experimental Child Psychology, 63, 358-385.

Walter. C. (2004). Transfer of reading comprehension skills to L2 is linked to mental representations of text and to L2 working memory. Applied Linguistics, 25, 315-339.

Waters, G. S. \& Caplan, D. (1996). The measurement of verbal working memory and its relation to reading comprehension. Quarterly Journal of Experimental Psychology, 49A, 51-74. 
Wen, Z. (2005). Foreign language aptitude research revisited. Xiandai Waiyu (Modern Foreign Languages), 4, 383-392.

Wen, Z. (2007). Working memory as foreign language aptitude: theory and practice. Xiandai Waiyu (Modern Foreign Languages), 1, 85-97.

Wesche, M. B. (1981). Language aptitude measures in streaming, matching students with methods, and diagnosis of learning problems. In K. C. Diller (Ed.), Individual differences and universals in language learning aptitude (pp. 119-154). Rowley, MA: Newbury House.

Wesche, M. B., H. Edwards, \& W. Wells. (1982). Foreign language aptitude and intelligence. Applied Psycholinguistics, 3, 127-140.

Williams, J. N. (1999). Learner-generated attention to form. Language Learning, 49, 583-625.

Williams, J. N. \& Lovatt, P. (2005). Phonological memory and rule learning. Language Learning 55: 177-233.

Yoshimura, Y. (2001). The role of working memory in language aptitude. In Bonch-Bruevich, X., Crawford, W. J., Hellermann, J., Higgins, C., and Nguyen, H. (Eds.), The Past, Present, and Future of Second Language Research: Selected Proceedings of the 2000 Second Language Research Forum. Somerville, MA: Cascadilla Press. 
